\title{
Faktor Penentu Dan Efek Bias Evaluasi Kinerja Di Perusahaan Indonesia
}

\author{
M.Sesilia Lidwina Y.S.S \\ Universitas Katolik Soegijapranata \\ Lidwinay90@gmail.com \\ Monika Palupi Murniati \\ palupi@unika.ac.id
}

\begin{abstract}
This study examines the determinants and effects of performance evaluation bias on manufacturing companies in Indonesia. The purpose of this study was to determine whether the information gathering costs and the relationship between manager and employee affect the emergence of centrality bias and leniency bias, and also to determine the effect of centrality bias and leniency bias on employee performance incentives.

The samples are all managers who work in large scale manufacturing companies located in Semarang. Sampling method by purposive sampling. Hypothesis testing is done by multiple regression. This study proves that: (1) The information gathering costs has positive influence on the centrality bias and leniency bias, (2) the relationship between manager and employee has positive influence on the centrality bias and leniency bias, (3) centrality bias does not affect the employee's performance incentives above average or below average, (4) leniency bias affects employee performance incentives.
\end{abstract}

Keywords : Information gathering costs, employee-manager relationships, centrality bias, leniency bias, performance incentives.

\begin{abstract}
Abstrak
Penelitian ini meneliti tentang faktor penentu dan efek dari bias evaluasi kinerja pada perusahaan manufaktur yang ada di Indonesia. Tujuan dari penelitian ini adalah untuk mengetahui apakah biaya pengumpulan informasi dan hubungan antara manajer dengan karyawan mempengaruhi munculnya centrality bias dan leniency bias, dan juga untuk mengetahui pengaruh centrality bias dan leniency bias terhadap performance incentives karyawan.

Sampel penelitian ini adalah semua manajer yang bekerja di perusahaan manufaktur skala menengah besar yang terdapat di Semarang. Metode pengambilan sampel secara purposive sampling. Pengujian hipotesis dilakukan dengan regresi berganda. Penelitian ini membuktikan bahwa : (1) Biaya pengumpulan informasi berpengaruh positif terhadap centrality bias dan leniency bias, (2) hubungan antara manajer dengan karyawan berpengaruh positif terhadap centrality bias dan leniency bias, (3) centrality bias tidak berpengaruh terhadap performance incentives karyawan yang di atas rata-rata maupun yang di bawah rata-rata, (4) Leniency bias mempengaruhi performance incentives karyawan.
\end{abstract}

Kata Kunci : Biaya Pengumpulan Informasi, Hubungan Manajer dengan Karyawan, Centrality bias, Leniency Bias, Performance Incentives. 


\section{PENDAHULUAN}

Penilaian kinerja merupakan hal yang sangat penting untuk dilakukan dalam perusahaan yang menerapkan sistem kompensasi berbasis kinerja. Sebab di dalam merancang sistem kompensasi yang baik, setidaknya itu harus memperhatikan dua segi yaitu person dan performance. Oleh karena itu, pemberian kompensasi didasarkan atas penilaian terhadap kinerja individu. Individu-individu yang mampu menyelesaikan tugasnya dengan baik akan memperoleh kompensasi yang tinggi, misalnya mendapatkan insentif berupa bonus. Sedangkan mereka yang berkinerja buruk akan mendapatkan kompensasi yang minimum.

Penilaian kinerja merupakan suatu tindakan yang dilakukan untuk menilai atau mengevaluasi dan untuk mengetahui apakah seorang karyawan telah melaksanakan pekerjaannya masing-masing secara baik atau tidak. Dalam melakukan penilaian kinerja itu diperlukan suatu pengukuran kinerja. Pengukuran ini dapat dilakukan secara objektif ataupun subjektif. Pengukuran kinerja secara objektif berarti pengukuran kinerja dapat diterima dan diukur pihak lain selain yang melakukan penilaian kinerja. Sedangkan pengukuran kinerja yang bersifat subyektif berarti dalam melakukan penilaian, manajer menggunakan pendapat pribadi dan preferensi mereka sendiri.

Dalam melakukan penilaian kinerja tersebut, bisa saja terjadi bias. Apalagi jika penilaian kinerja terhadap karyawan dilakukan dengan ukuran subjektif dan tidak lepas dari unsur emosional para penilai. Berbeda dengan penilaian kinerja secara objektif yang mempunyai ukuran-ukuran yang objektif dan terverifikasi, penilaian kinerja secara subjektif itu lebih mengandalkan judgement penilai sehingga sangat rentan terhadap bias-bias keperilakuan (Bol 2008; Gibbs et al. 2004; Prendergast dan Topel 1996). Dengan demikian terjadi peluang munculnya bias evaluasi kinerja. Bias merupakan distorsi pengukuran yang tidak akurat.

Seperti penelitian yang dilakukan oleh Bol (2011), dimana Bol ingin menguji bagaimana bias penilaian kinerja mempengaruhi efektivitas kontrak insentif berbasis kinerja. Penelitian tersebut, berfokus pada bias centrality dan bias leniency. Dimana munculnya kedua bias ini sangat dipengaruhi oleh biaya pengumpulan informasi dan hubungan manajer dengan karyawan yang memiliki hubungan baik. Dalam melakukan penilaian kinerja terhadap karyawan, manajer diharapkan mampu menilai karyawan secara objektif. Padahal agar dapat melakukan penilaian yang objektif itu diperlukan pengumpulan informasi yang lengkap mengenai kinerja karyawan.

Namun, biaya untuk pengumpulan informasi tersebut sangatlah mahal. Apalagi jika manajer tidak dapat mengamati tindakan karyawan dan dengan demikan manajer harus memberikan waktu ekslusif mereka untuk memantau karyawan. Karena itulah manajer mulai memiliki preferensi untuk membatasi waktu dan usaha yang dihabiskan untuk melakukan evaluasi kinerja. Hal ini menyebabkan pengumpulan informasi yang tidak lengkap. Dan karena pengumpulan informasi yang tidak lengkap ini, kemudian mendorong terjadinya bias dalam evaluasi kinerja.

Selain itu, manajer dan karyawan yang memiliki hubungan baik juga menyebabkan penilaian secara subyektif. Sebab kondisi ini menjadikan beban bagi manajer atau orang yang melakukan penilaian kinerja karena salah-salah hubungan antara yang dinilai dan yang menilai menjadi ikut terganggu. Sehingga hal ini juga mendorong terjadi bias evaluasi kinerja. Bias leniency dan bias centrality merupakan bentuk bias yang terjadi dalam penilaian kinerja yang subjektif (Golman dan Bhatia 2012; Bol 2011; Moers 2005).

Bias terhadap penilaian kinerja ini akan memberikan efek atau akibat negatif bagi karyawan maupun perusahaan. Seperti yang diungkapkan dalam literatur ekonomi yang dilakukan oleh Golman dan Bhatia (2012), menyatakan bahwa bias dalam penilaian kinerja sangat dianggap berbahaya bagi kinerja jangka panjang perusahaan karena memberikan dampak negatif terhadap usaha dan produktivitas karyawan serta mendistorsi upah. Selain itu, 
ada juga dukungan terhadap dampak negatif bias penilaian kinerja yang ditunjukkan melalui bukti empiris. Seperti hasil eksperimen laboratorium Berger et al. (2010) yang menunjukkan bahwa penilaian kinerja yang diberikan oleh penilai secara murah hati mengakibatkan penurunan kinerja karyawan dalam jangka panjang. Dengan demikian, bias dalam penilaian kinerja ini sangat memberikan efek dan dampak negatif bagi karyawan maupun bagi produktivitas perusahaan ke depannya.

Hasil penelitian Bol (2011), menunjukkan bahwa manajer menanggapi preferensi mereka sendiri ketika subjektif mengevaluasi kinerja. Selain itu, pengumpulan informasi dan hubungan karyawan dengan manajer yang kuat positif mempengaruhi bias centrality dan bias leniency. Hasil penelitian Bol (2011) juga menunjukkan bahwa bias tidak hanya mempengaruhi kinerja saat ini tetapi juga insentif karyawan di masa depan nanti. Meskipun bias centrality berpengaruh negatif terhadap peningkatan kinerja, bukti tidak mengungkapkan hubungan negatif antara bias leniency dan kinerja. Sebaliknya, Bol menemukan bahwa bias leniency mempengaruhi kinerja secara positif. Kelemahan riset Bol (2011) ini adalah petama, kemampuan untuk menggeneralisasi temuan dibatasi oleh ketergantungan pada data dari satu perusahaan saja. Kedua, riset tersebut dilakukan di negara Belanda, padahal di negara Belanda sistem kompensasi berbasis kinerja memainkan peran yang kurang menonjol.

Dari kelemahan riset sebelumnya, maka peneliti ingin melakukan penelitian di negara yang memiliki sistem kompensasi berbasis kinerja yang dominan. Sebab akan lebih menarik untuk menguji apakah efek yang ditemukan dalam penelitian sebelumnya akan menjadi lebih kuat di negara-negara dimana sistem kompensasi berbasis kinerja memainkan peran yang lebih dominan. Karena basis kompensasi yang berbeda ini akan menimbulkan efek yang berbeda juga. Misalnya saja, suatu perusahaan menerapkan kompensasi berbasis kinerja dan perusahaan lainnya menerapkan kompensasi berbasis "Job Value (nilai jabatan)" maka akan menimbulkan efek yang berbeda.

Penelitian yang dilakukan oleh Denni (2010) mengungkapkan bahwa dengan menerapkan kompensasi berbasis job value/nilai jabatan ini, maka gaji pokok yang diterima seorang karyawan relatif akan sama dengan orang lain yang menduduki jabatan dengan nilai jabatan yang sama. Hal ini akan menimbulkan ketidakpuasan dari individu yang memiliki kompetensi yang lebih tinggi dibandingkan dengan individu yang lain, meskipun tiap individu tersebut mempunyai pengalaman dan pendidikan yang sama. Metode evaluasi kompensasi yang menerapkan job value (nilai jabatan) menggunakan asumsi yang sama pada basis perhitungannya, yaitu setiap pemangku jabatan memiliki kinerja yang sama $100 \%$. Sehingga dengan menggunakan basis job value ini, maka gaji seorang pemangku jabatan pada nilai jabatan yang sama ditetapkan sama. Oleh karena itu, biasanya orang-orang yang memiliki kompetensi atau kemampuan yang lebih tinggi dari orang lain akan merasa jika sistem penggajian semacam ini kurang adil bagi mereka yang memiliki kompetensi yang lebih.

Maka dari itu, kemudian perusahaan-perusahan mulai membuat desain sistem kompensasi dengan memperhitungkan elemen person value (nilai orang). Dimana desain sistem kompensasi berbasis Person Value (Nilai Orang) akan ditentukan oleh kompetensi atau kinerja yang dimiliki tiap karyawan, yang sesuai dengan kebutuhan organisasi atau jabatan yang dipangku oleh karyawan tersebut.

Oleh karena itu, jika suatu perusahaan menerapkan sistem kompensasi yang berbasis job value/nilai jabatan (insentif yang diterima seorang karyawan relatif sama dengan karyawan lain yang memiliki jabatan yang sama) akan berbeda dengan perusahaan yang menerapkan kompensasi berbasis kinerja. Karena jika berbasis job value, maka bias dalam evaluasi kinerja tidak berpengaruh terhadap efektivitas sistem kompensasi sebab yang menjadi ukuran penilaian adalah jabatan bukan kinerja karyawan. Sedangkan dalam perusahaan yang menerapkan kompensasi berbasis kinerja, bias dalam evaluasi kinerja ini tentu sangat mempengaruhi efektivitas sistem kompensasi, sebab yang menjadi ukuran penilaian adalah 
kinerja karyawan. Sehingga jika terdapat bias dalam evaluasi kinerja tentu akan mempengaruhi performance insentif karyawan.

Maka peneliti ingin menguji faktor penentu dan efek dari bias evaluasi kinerja di perusahaan yang ada di Indonesia. Sebab negara-negara asia pasifik merupakan negara yang sangat dominan dalam penerapan sistem kompensasi berbasis kinerja. Indonesia termasuk dalam negara asia pasifik yang sangat dominan dalam penerapan sistem kompensasi berbasis kinerja.

\section{TINJAUAN LITERATUR DAN PERUMUSAN HIPOTESIS}

\section{Teori Keagenan (Agency Theory)}

Teori keagenan menjelaskan mengenai hubungan antara pemegang saham (shareholders) sebagai prinsipal dan manajemen sebagai agen.Hubungan keagenan merupakan suatu kontrak dimana satu atau lebih orang (prinsipal) memerintah orang lain (agen) untuk melakukan suatu jasa atas nama prinsipal dan memberikan wewenang kepada agen dalam membuat keputusan yang terbaik bagi prinsipal atau pemegang saham. Sehingga apabila agen dan prinsipal tersebut mempunyai tujuan yang sama untuk memaksimumkan nilai perusahaan, maka diyakini agen akan bertindak dengan cara yang sesuai dengan kepentingan prinsipal (Kusdi,2009).

Masalah keagenan terjadi apabila bagian kepemilikan manajer atas saham perusahaan kurang dari seratus persen (Masdupi, 2005). Dengan proporsi kepemilikan yang hanya sebagian dari perusahaan atau kurang dari $100 \%$ maka hal ini akan membuat manajer cenderung bertindak untuk kepentingannya sendiri dan bukan untuk memaksimumkan perusahaan. Inilah yang menyebabkan biaya keagenan (agency cost). Jensen dan Meckling (1976) mendefinisikan agency cost sebagai jumlah dari biaya yang dikeluarkan prinsipal untuk melakukan pengawasan terhadap agen. Sebab sangat mustahil bagi perusahaan untuk memiliki zero agency cost dalam rangka menjamin manajer akan mengambil keputusan yang optimal dari pandangan shareholders karena adanya perbedaan kepentingan yang besar diantara mereka.

Fokus dari teori keagenan ini yaitu penentuan kontrak yang paling efisien dan efektif yang mendasari hubungan antara agen dengan prinsipal. Agar agen dapat termotivasi maka prinsipal merancang suatu kontrak agar dapat mengakomodasi kepentingan pihak-pihak yang terlibat dalam kontrak keagenan.

Dalam teori keagenan ini, agen menginginkan kepentingannya diakomodir dengan cara pemberian kompensasi/ insentif/bonus yang memadai dan sebesar-besarnya atas kinerjanya. Principal akan menilai prestasi Agen berdasarkan kemampuannya memperbesar laba. Sehingga semakin tinggi laba atau harga saham, maka Agen akan dianggap berhasil dan berkinerja baik (Kusdi,2009).

\section{Teori Ekuitas}

Teori Ekuitas merupakan salah satu teori keadilan. Teori ini dikemukaan oleh John Stacey Adams pada tahun 1963. Teori Ekuitas ini menekankan bahwa dalam teori ekuitas ini sangat identik dengan istilah "input" dan "output". Input (masukan) dapat diartikan sebagai apa yang kita berikan atau masukkan ke dalam pekerjaan kita, seperti usaha, waktu, keandalan, loyalitas, dan komitmen. Sedangkan output (keluaran) merupakan segala sesuatu yang kita dapatkan sebagai hasil dari masukan yang kita berikan, misalnya bonus, gaji, dan tunjangan. Orang akan menjadi demotivasi/tidak termotivasi dan mengurangi masukan (input) mereka apabila mereka merasa usahanya tidak dihargai secara adil (Kusdi, 2009).

Ketika orang merasa diperlakukan secara adil maka mereka akan lebih cenderung termotivasi, sebaliknya ketika mereka merasa diperlakukan secara tidak adil maka mereka akan 
merasa tidak puas dan demotivasi. Cara seseorang mengukur rasa keadilan adalah inti dari teori ekuitas.

\section{Teori Ketidaksesuaian (Discrepancy Theory)}

Teori ketidaksesuaian (Discrepancy Theory) ini dikemukakan oleh Locke pada tahun 1961. Teori ini mengungkapkan bahwa kepuasan dan ketidakpuasan terhadap aspek pekerjaan tergantung pada kesenjangan (discrepancy) antara persepsi karyawan mengenai apa yang ia peroleh dengan apa yang ia inginkan (Kusdi, 2009).

Dengan demikian, orang akan merasa puas bila tidak ada perbedaan antara apa yang diinginkan dengan apa yang kenyataan didapatkan. Apabila yang didapat ternyata lebih besar daripada yang diinginkan, maka orang akan menjadi lebih puas lagi walaupun terdapat discrepancy, tetapi hal tersebut merupakan discrepancy atau kesenjangan yang positif. Sebaliknya, semakin jauh kenyataan apa yang diinginkan dengan apa yang didapatkan berada di bawah standar minimum yang mereka inginkan maka menyebabkan negative discrepancy, maka ketidakpuasan seseorang terhadap pekerjaannya akan semakin lebih besar. Ketidakpuasan kerja dapat terjadi ketika terdapat ketidaksesuaian antara pendapatan yang diterima dengan keinginan. Contohnya, banyak karyawan mendapatkan gaji yang tidak sesuai kemudian merasa tidak puas. Sehingga dapat disimpulkan bahwa sikap karyawan terhadap pekerjaannya itu tergantung dari discrepancy atau ketidaksesuaian yang dirasakan oleh karyawan.

Jadi, teori ketidaksesuaian ini dapat disumpulkan bahwa teori ini menekankan pada selisih antara kondisi yang diinginkan dengan kondisi yang sebenarnya terjadi.Sehingga jika terdapat perbedaan antara keinginan dengan kenyataan maka orang akan menjadi merasa tidak puas. Tetapi jika kondisi yang diinginkan dan yang didapat ternyata sesuai, maka orang akan merasa puas.

\section{Teori Penilaian Kinerja (Theory Of Rating)}

Teori penilaian kinerja ini dikemukakan oleh Wherry dan Bartlett (1982). Menurut teori ini, penilaian kinerja terdiri dari dua proses yaitu observation dan judgement, dan keduanya merupakan persoalan terhadap bias. Apabila penilaian tergantung pada judgment seseorang, maka hal ini sangat rentan terhadap terjadinya bias evaluasi kinerja. Semua metode yang ada untuk melakukan penilaian kinerja berusaha untuk mengurangi terjadinya bias, namun tetap saja tidak ada metode yang benar-benar dapat terbebas dari terjadinya bias evaluasi kinerja.

Bias-bias yang terjadi ini dipengaruhi oleh faktor penilai/raters yang dikarenakan penilai/raters kekurangan pengetahuan akan kinerja karyawan. Kemudian juga dipengaruhi oleh faktor orang yang dinilai/ratees seperti jenis kelamin, usia kerja. Dan yang terakhir, terjadinya bias karena didorong oleh interaksi penilai/raters dengan orang yang dinilai/ratees yang dapat dipengaruhi oleh ras dan gender.

Di dalam teori ini menjelaskan mengenai faktor-faktor selain kinerja aktual pihak yang dinilai yang memengaruhi penilaian kinerja dan mengidentifikasi metode yang dapat digunakan untuk mengurangi bias yang dialami oleh penilai dalam melakukan evaluasi kinerja. Keakuratan atau ketepatan penilaian kinerja yang diberikan oleh penilai sangat tergantung pada tiga langkah yaitu: kinerja pihak yang dinilai, pengamatan penilai terhadap kinerja, dan ingatan penilai mengenai pengamatan yang telah dilakukan.

\section{Perumusan Hipotesis}

Dalam melakukan penilaian terhadap kinerja karyawan terdapat dua tipe penilaian kinerja yang dapat dilakukan yaitu penilaian kinerja secara objektif dan penilaian kinerja secara subjektif. Untuk dapat melakukan penilaian secara objektif ini diperlukan berbagai informasi dan data, baik itu data berupa data produksi (volume penjualan dolar, unit yang diproduksi, jumlah kesalahan, jumlah produk cacat) serta data kerja (kecelakaan, turnover, absen, 
keterlambatan). Agar dapat memperoleh informasi data yang lengkap tersebut sangat diperlukan waktu dan upaya yang besar untuk melakukan pengawasan terhadap indikatorindikator kinerja karyawan. Oleh karena itu, biaya yang dikeluarkan perusahaan untuk memperoleh informasi mengenai kinerja karyawan tersebut harus efektif dan efisien. Sehingga informasi data kinerja yang diperoleh perusahaan dapat lengkap. Jika informasi yang dimiliki perusahaan lengkap maka hal ini dapat membantu para manajer untuk melakukan penilaian kinerja secara objektif dan informasi yang lengkap ini dapat mengurangi bias yang terjadi dalam evaluasi penilaian kinerja. Sebab jika biaya yang dikeluarkan untuk pengumpulan informasi ini mahal dan biaya yang dikeluarkan tidak efektif maka hal ini menyebabkan data informasi mengenai kinerja karyawan menjadi tidak lengkap. Hal ini mendorong manajer/penilai cenderung bertindak untuk kepentingan pribadi mereka.

Dalam teori keagenan menjelaskan hubungan antara pemegang saham (prinsipal) dan manajemen (agen). Dimana manajemen dikontrak untuk kepentingan pemegang saham dan diberi wewenang untuk membuat keputusan yang terbaik untuk memaksimalkan nilai perusahaan. Namun dalam hubungan keagenan ini, manajer cenderung bertindak untuk kepentingan pribadi mereka, bukan untuk memaksimalkan nilai perusahaan. Sebab hal ini dikarenakan pemegang saham (prinsipal) hanya memiliki sedikit informasi mengenai perusahaan sehingga tindakan manajemen (agen) akan sulit diamati. Dengan demikian membuka peluang manajemen (agen) untuk memaksimalkan kepentingan pribadinya. Ketika manajer memiliki tujuan untuk memaksimalkan kepentingan pribadinya, maka manajer akan membatasi waktu dan tenaga/upaya untuk melakukan pengawasan terhadap karyawan. Hal ini menyebabkan informasi data yang diperlukan untuk evaluasi kinerja karyawan menjadi tidak lengkap sehingga menyebabkan bias dalam penilaian kinerja.

Seperti yang diungkapkan oleh Harris (1994), yang menyatakan bahwa biaya pengumpulan informasi yang tinggi dan tidak efektif tersebut akan membuat penilai/raterskurang bersedia untuk meluangkan waktu yang diperlukan dalam pengumpulan informasi tersebut. Hal ini menyebabkan data informasi yang dibutuhkan untuk melakukan evaluasi kinerja karyawan tidak lengkap sehingga informasi data menjadi tidak reliabel dan terjadi modifikasi kinerja karyawan oleh karakteristik situasional. Karena data yang tidak lengkap itulah kemudian mendorong penilai/ratersuntuk melakukan penilaian kinerja secara subjektif. Padahal penilaian kinerja secara subjektif ini sangat rentan terhadap munculnya bias. Salah satunya yaitu centrality bias.

Dengan informasi data yang terbatas, maka manajer/penilai tidak mengetahui secara pasti kinerja masing-masing karyawan, mana karyawan yang memiliki kinerja yang baik maupun mana karyawan yang memiliki kinerja yang buruk. Sebalik jika biaya yang dikeluarkan perusahaan untuk memperoleh data informasi kinerja perusahaan itu efektif dan efisien, maka informasi data mengenai kinerja karyawan akan lengkap sehingga manajer/penilai dapat mengetahui pasti kinerja masing-masing karyawan, mana karyawan yang berkinerja baik dan mana karyawan yang berkinerja buruk. Jadi jika biaya pengumpulan informasi yang dikeluarkan itu efektif maka akan mengurangi terjadinya centrality bias. Namun, jika biaya pengumpulan informasi yang dikeluarkan terlalu tinggi dan tidak efektif maka hal itu akan semakin mendorong munculnya centrality bias. Dengan demikian, biaya pengumpulan informasi memiliki pengaruh terhadap munculnya centrality bias.

Dalam penelitian yang dilakukan oleh Bol (2007), menunjukkan hasil bahwa penilaian kinerja subjektif itu dipengaruhi oleh biaya pengumpulan informasi,dan biaya evaluasi. Dari penjelasan di atas, maka dapat dibuat suatu hipotesis bahwa :

\section{$H_{1}$ : Biaya pengumpulan informasi berpengaruh negatif terhadap centrality bias.}

Penilaian kinerja itu dapat bersifat objektif maupun subjektif. Penilaian kinerja secara objektif berarti penilaian yang dilakukan memiliki ukuran-ukuran yang objektif dan 
terverifikasi. Sedangkan penilaian kinerja secara subjektif berarti dalam melakukan penilaian, manajer menggunakan pendapat pribadi dan preferensi mereka sendiri.

Penilaian kinerja secara subjektif ini terjadi ketika data yang berisi informasi kinerja karyawan itu tidak lengkap. Ketidaklengkapan informasi ini disebabkan karena ketidakefektifan biaya yang dikeluarkan untuk pengumpulan informasi, baik itu informasi mengenai data produksi dan data kerja sehingga menyebabkan biaya yang dikeluarkan menjadi mahal dan tidak efektif. Hal inilah yang kemudian mendorong manajer untuk melakukan penilaian kinerja secara subjektif.

Padahal penilaian kinerja secara subjektif ini sangat rentan terhadap munculnya bias dalam evaluasi kinerja. Salah satunya yaitu munculnya leniency bias. Sebab, dengan informasi data yang terbatas, maka manajer/penilai akan lebih berhati-hati dalam memberikan penilaian kinerja karyawan sebab jika karyawan merasa tidak puas dengan hasil evaluasi kinerja yang diterimanya maka karyawan akan melakukan protes terhadap manajer/penilai untuk melakukan pembenaran dan untuk memeriksa kembali hasil evaluasi kinerja yang mereka terima. Tentu saja hal ini sangat dihindari oleh manajer/penilai. Sebab proses untuk melakukan pemeriksaan kembali hasil evaluasi kinerja itu membutuhkan banyak waktu dan juga manajer/penilai harus mengumpulkan informasi tambahan mengenai kinerja karyawan tersebut. Oleh karena itu, manajer/penilai akan memberikan penilaian yang lebih tinggi dari keadaan sebenarnya untuk menghindari protes dari karyawan. Dengan demikian, biaya pengumpulan informasi ini mempunyai pengaruh terhadap munculnya leniency bias.

Hal ini juga sejalan dengan teori keagenan. Dimana dalam teori ini diungkapkan bahwa dalam hubungan keagenan, manajer cenderung bertindak untuk kepentingan pribadi mereka, bukan untuk kepentingan perusahaan. Sehingga ketika manajer ini bertindak demi kepentingan pribadinya maka manajer akan membatasi waktu dan upaya untuk melakukan pengawasan terhadap kinerja karyawan. Hal ini menyebabkan informasi mengenai karyawan menjadi tidak lengkap sehingga manajer menggunakan penilaian secara subjektif dan memunculkan leniency bias.

Dalam penelitian yang dilakukan oleh Moers (2005), menunjukkan bahwa penilaian kinerja subjektif muncul ketika informasi mengenai karyawan tidak lengkap sehingga mendorong munculnya leniency bias. Sebaliknya, ketika perusahaan memiliki informasi yang lengkap maka hal itu akan membuat manajer/penilai dapat melakukan evaluasi kinerja secara objektif dan mengurangi terjadinya leniency bias. Dari penjelasan di atas, maka dapat dibuat suatu hipotesis sebagai berikut :

\section{$\mathrm{H}_{2}$ : Biaya pengumpulan informasi berpengaruh negatif terhadap leniency bias.}

Dalam teori penilaian kinerja (Theory of Rating) menyatakan bahwa penilaian kinerja itu terdiri dari dua proses yaitu observation dan judgement. Keduanya tidak lepas dari persoalan bias. Dalam teori penilaian kinerja ini, bias-bias yang muncul dalam evaluasi penilaian kinerja disebabkan oleh penilai/raterskekurangan informasi akan kinerja karyawan,interaksi/hubungan penilai/raters dengan orang yang dinilai/ratees, variasi situasional dan karakteristik organisasi.

Seperti yang dijelaskan dalam teori penilaian kinerja, bahwa hubungan antara manajer dengan karyawan dapat memunculkan bias dalam evaluasi kinerja, salah satunya dapat memunculkan centrality bias. Dimana manajer akan memberikan penilaian yang sama terhadap semua karyawan, sehingga karyawan yang kinerjanya baik maupun karyawan yang kinerjanya buruk akan dinilai dibawah rata-rata sehingga mereka akan memiliki nilai yang sama. Sebab jika manajer melakukan penilaian secara akurat, maka manajer takut akan menimbulkan kritik, protes dari karyawan dan dapat menimbulkan konflik dengan karyawan yang menyebabkan terganggunya hubungan manajer dengan karyawan sebagaimana mestinya. Sehingga jika semua karyawan memiliki nilai yang sama, maka karyawan akan merasa bahwa 
penilaian manajer itu adil. Hal ini akan membuat hubungan antara manajer dengan karyawan berkinerja buruk pun akan tetap terjaga dengan baik.

Dalam penelitian yang dilakukan oleh Breuer et al (2010) juga menyatakan bahwa bias evaluasi kinerja muncul ketika adanya jarak sosial yang dekat antara atasan dengan bawahan. Selain itu, hal ini juga didukung oleh penelitian yang dilakukan Golman dan Bhatia (2012), yang menunjukkan hasil bahwa hubungan yang dekat antara manajer dengan karyawan akan meningkat penilaian kinerja yang subjektif. Dari penjelasan di atas, maka dapat dibuat hipotetis sebagai berikut:

\section{H3: Hubungan antara manajer dengan karyawan berpengaruh positif terhadap centrality bias.}

Menurut teori penilaian kinerja (Theory of Rating) yang dikemukakan oleh Wherry dan Bartlett (1992) bahwa bias-bias yang muncul dalam evaluasi kinerja disebabkan oleh penilai/raters kekurangan informasi akan kinerja karyawan, interaksi/hubungan penilai/raters dengan yang dinilai/ratees, variasi situasional dan karakteristik organisasi.

Interaksi atau hubungan yang baik antara penilai dengan orang yang dinilai ini menyebabkan penilaian kinerja yang subjektif. Penilaian kinerja yang subjektif ini, kemudian mendorong munculnya bias evaluasi kinerja. Jika manajer memiliki hubungan yang baik dengan karyawannya, maka manajer tersebut cendurung akan memberikan penilaian yang baik terhadap karyawan tersebut meskipun sebenarnya tidak memiliki kinerja yang baik. Sebab kondisi ini menjadikan beban bagi manajer atau orang yang melakukan penilaian kinerja karena salah-salah hubungan yang dinilai dan yang menilai ikut rusak atau terganggu. Sebab jika manajer melakukan penilaian secara apa adanya, maka manajer takut akan menimbulkan kritik, protes dari karyawan dan dapat menimbulkan konflik dengan karyawan yang menyebabkan terganggunya hubungan manajer dengan karyawan sebagaimana mestinya. Hal ini membuat manajer/penilai memberikan penilaian yang sangat baik/ memberikan nilai yang tinggi untuk semua karyawan. Dengan demikian hubungan yang baik antara manajer dengan karyawan dapat memunculkan leniency bias. Dari penjelasan di atas, maka dapat dibuat suatu hipotesis sebagai berikut :

\section{$\mathrm{H}_{4}$ : Hubungan antara manajer dengan karyawan berpengaruh positif terhadap leniency bias.}

Menurut teori ekuitas menyatakan bahwa para karyawan berusaha untuk mempertahankan keadilan antara input yang mereka bawa ke pekerjaan dan hasil yang mereka terima dari itu terhadap masukan dan hasil yang dirasakan orang lain. Input merupakan apa yang diberikan dalam pekerjaan, meliputi waktu ,usaha, fleksibelitas, keandalan, dll. Sedangkan output merupakan segala sesuatu yang didapatkan sebagai hasilnya, meliputi gaji, tunjangan, bonus, dll. Menurut teori ekuitas ini, setiap karyawan cenderung membandingkan input dan output mereka dengan karyawan lain. Dan jika mereka merasa output yang diperoleh tidak adil/ tidak sebanding maka mereka akan merasa tidak puas dan demotivasi. Ketika usaha mereka dinilai secara tidak adil, maka mereka akan menurunkan input yang mereka berikan.

Oleh karena itu, jika terjadi centrality bias dalam penilaian kinerja karyawan, dimana semua karyawan prestasinya dinilai dibawah rata-rata yang seharusnya, maka hal ini akan menimbulkan ketidakpuasan terhadap karyawan yang sebenarnya memiliki kinerja yang jauh lebih baik dibanding karyawan lainnya namun malah diberi nilai yang sama dengan karyawan yang memiliki kinerja lebih buruk darinya. Tentu saja hal ini akan memberikan dampak atau pengaruh negatif terhadap kinerja karyawan tersebut.

Hal ini juga sejalan dengan teori ketidaksesuaian/discrepancy theory yang dikemukakan oleh Locke. Dimana teori ini menyatakan bahwa kepuasan dan ketidakpuasan terhadap aspek pekerjaan tergantung pada kesenjangan (discrepancy) antara persepsi karyawan mengenai apa 
yang ia peroleh dengan apa yang dia inginkan. Dari teori ketidaksesuaian ini dapat disimpulkan bahwa setiap karyawan pasti memiliki keinginan untuk memperoleh gaji/bonus yang besar, apalagi jika karyawan tersebut memiliki kinerja yang baik tentu saja ia akan mengharapkan gaji / bonus yang diterimanya semakin besar. Namun, jika terjadi centrality bias dalam penilaian kinerja karyawan maka hal tersebut akan memberikan ketidakpuasan terhadap karyawan yang memiliki kinerja yang baik sehingga berpengaruh negatif terhadap kinerja karyawan yang berada di atas rata-rata.

Selain itu, hal ini juga sejalan dengan teori keagenan. Dalam teori ini, agen menginginkan kepentingannya diakomodir dengan pemberian kompensasi/ bonus/insentif/remunersi yang "memadai" dan sebesar-besarnya atas kinerjanya. Sehingga jika karyawan yang memiliki kinerja yang baik namun ia memperoleh gaji/bonus yang sama dengan karyawan yang memiliki kinerja di bawahnya, maka hal tersebut akan membuat karyawan ini merasa tidak puas dan akan menurunkan kinerjanya, karena merasa usahanya tidak dihargai.

Oleh karena itu, centrality bias dapat berpengaruh negatif terhadap kinerja dan insentif karyawan yang memiliki kinerja yang baik. Sebab, setiap karyawan dinilai sama oleh penilai, sehingga baik karyawan yang memiliki kinerja yang baik maupun kinerja yang buruk, semua diberi nilai yang sama. Hal ini menyebabkan karyawan yang memiliki kinerja yang baik akan merasa tidak adil dan merasa kinerjanya tidak dihargai oleh perusahaan karena mereka diberi nilai yang sama dengan karyawan yang kinerjanya buruk. Dengan demikian, karyawan yang merasa kinerjanya tidak dihargai tersebut maka akan menurunkan kinerjanya. Selain berpengaruh negatif terhadap kinerja karyawan, centrality bias ini juga berpengaruh negatif terhadap insentif karyawan yang memiliki kinerja yang baik tersebut. Sebab seharusnya karyawan yang memiliki kinerja baik memperoleh insentif yang lebih tinggi dibanding mereka yang berkinerja buruk. Namun, dengan terjadinya centrality bias ini menyebabkan jumlah insentif yang diterima karyawan yang berkinerja baik itu menjadi sama dengan karyawan yang kinerjanya buruk. Dari penjelasan diatas, maka dapat dibuat hipotesis sebagai berikut :

\section{H5: Centrality bias berpengaruh negatif terhadap performance incentive karyawan yang di atas rata-rata.}

Centrality bias dapat memberikan pengaruh negatif bagi kinerja dan insentif karyawan khususnya mereka yang memiliki kinerja yang baik (di atas rata-rata). Namun, hal ini akan berbeda untuk karyawan yang memiliki kinerja buruk (di bawah rata-rata). Dimana centrality bias ini dapat berpengaruh positif terhadap kinerja dan insentif karyawan yang kinerjanya di bawah rata-rata. Sebab karyawan yang di bawah rata-rata, namun memperoleh insentif yang sama dengan karyawan yang kinerjanya jauh lebih baik, maka hal tersebut akan memotivasi karyawan, sehingga kinerja karyawan pun akan meningkat. Karyawan yang kinerjanya di bawah rata-rata ini akan termotivasi kinerjanya karena mereka merasa adil dan puas terhadap hasil penilaian kinerja yang dilakukan oleh penilai/raters.

Hal ini sejalan dengan teori ketidaksesuaian (discrepancy theory), dimana teori ini menyatakan bahwa kepuasan atau ketidakpuasan karyawan terhadap pekerjaannya tergantung pada kesenjangan antara persepsi karyawan mengenai apa yang diperoleh dan apa yang diinginkan. Apabila yang didapat ternyata lebih besar dari apa yang diinginkannya, maka orang akan merasa lebih puas. Meskipun terdapat discrepancy, namun hal ini merupakan discrepancy yang positif. Dan menurut teori ini, sikap karyawan terhadap pekerjaannya tergantung dari bagaimana discrepancy tersebut dirasakannya. Sehingga jika yang dirasakan oleh karyawan adalah discrepancy yang positif maka karyawan akan meningkatkan kinerjanya.

Selain berpengaruh positif, Centrality bias juga dapat memberikan pengaruh negatif terhadap kinerja karyawan yang berada di bawah rata-rata. Sebab, karyawan yang memiliki kinerja di bawah rata-rata menganggap diri mereka sama dengan karyawan yang memiliki kinerja yang baik. Selain itu, penilaian kinerja yang tidak variasi tersebut membuat karyawan 
yang di bawah rata-rata merasa enggan untuk meningkatkan kinerja mereka, karena dengan kinerja yang buruk saja mereka dapat memperoleh insentif yang sama dengan mereka yang berkinerja baik. Maka dari itu, dapat dibuat suatu hipotesis bahwa :

\section{H6 : Centrality bias berpengaruh terhadap performance incentive karyawan yang Di bawah rata-rata.}

Menurut discrepancy theory, kepuasaan atau ketidakpuasaan karyawan terhadap pekerjaannya itu tergantung dari kesenjangan antara apa yang diinginkan dengan apa yang diperoleh karyawan tersebut. Jika yang didapatkan karyawan ternyata lebih besar dari apa yang diinginkannya maka karyawan akan merasa puas. Semakin karyawan merasa puas, maka karyawan akan semakin meningkatkan kinerjanya. Sehingga jika dalam evaluasi kinerja terjadi leniency bias, maka hal ini akan berpengaruh positif terhadap kinerja maupun insentif karyawan. Dimana leniency bias ini merupakan situasi ketika manajer/penilai memberikan penilaian yang terlalu baik/terlalu tinggi dibandingkan dengan keadaan sebenarnya. Dengan demikian, insentif yang diterima karyawan akan jauh lebih tinggi dari apa yang seharusnya diterima oleh karyawan tersebut. Oleh karena itu, karyawan akan merasa termotivasi untuk meningkatkan kinerjanya.

Namun, leniency bias ini dapat berdampak negatif terhadap kinerja dan insentif karyawan. Dalam penelitian Golman dan Bhatia (2012), menunjukkan bahwa leniency bias ini berdampak negatif terhadap usaha dan produktivitas karyawan dalam jangka panjang dan juga leniency bias ini mendistorsi upah. Selain itu, hal ini juga didukung oleh penelitian yang dilakukan Gurbuz dan Dikmenli (2007), yang menyatakan bahwa sangat sulit bagi ratees melihat semua orang mendapatkan penilaian yang sama dan ratees menganggap sistem penilaian tersebut tidak adil, meskipun penilaian yang dilakukan tersebut mengacu pada leniency bias. Sehingga kesalahan peniliaian tersebut dapat melemahkan motivasi kerja dan kinerja karyawan. Dari penjelasan tersebut, dapat dibuat suatu hipotesis sebagai berikut :

\section{$\mathrm{H}_{7}$ : Leniency bias berpengaruh terhadap performance incentive karyawan.}

\section{METODE PENELITIAN}

\section{Populasi dan Sampel}

Populasi merupakan kelompok elemen yang lengkap yang biasanya berupa orang, obyek, transaksi atau kejadian di mana kita tertarik untuk mempelajarinya atau menjadi obyek penelitian. Populasi dalam penelitian ini adalah semua manajer yang bekerja pada perusahaan manufaktur di Semarang. Alasan digunakannya perusahaan manufaktur adalah lebih menggambarkan orientasi performance incentive. Sampel merupakan suatu bagian dari unit populasi, yang dipilih dengan menggunakan prosedur tertentu sehingga diharapkan dapat mewakili populasinya. Teknik pengambilan sampel pada penelitian ini menggunakan metode purposive sampling, yaitu teknik pengambilan sampel yang menggunakan kriteria tertentu. Tabel 1 menyajikan jumlah responden yang digunakan dalam penelitian. Dari tabel 1 dapat dilihat bahwa dari 376 perusahaan manufaktur berskala menengah dan besar di Semarang, hanya sebanyak 22 perusahaan yang bersedia menerima kuesioner. 
Tabel 1.

Responden Penelitian

\begin{tabular}{|l|c|}
\hline \multicolumn{1}{|c|}{ Keterangan } & Jumlah \\
\hline $\begin{array}{l}\text { Perusahaan manufaktur skala menengah besar di } \\
\text { Semarang. }\end{array}$ & 376 \\
\hline $\begin{array}{l}\text { Perusahaan yang tidak lengkap datanya sehingga tidak } \\
\text { dapat dihubungi. }\end{array}$ & $(83)$ \\
\hline $\begin{array}{l}\text { Perusahaan yang tidak dapat diidentifikasi } \\
\text { tempat/letak perusahaan dan jauh dari jangkauan } \\
\text { peneliti. }\end{array}$ & $(271)$ \\
\hline $\begin{array}{l}\text { Perusahaan yang bersedia berpartisipasi dalam } \\
\text { penelitian. }\end{array}$ & 22 \\
\hline
\end{tabular}

Jenis data pada penelitian ini adalah data primer. Data primer merupakan jenis dan sumber data yang diperoleh secara langsung dari sumber pertama atau tidak melalui perantara. Dalam penelitian ini data primer yang digunakan adalah data-data yang diperoleh langsung dari obyek penelitian. Adapun data-data tersebut meliputi identitas responden dan tanggapan responden yang akan dijawab langsung oleh responden mengenai variabel-variabel pada penelitian ini.

Data tersebut dikumpulkan dengan menggunakan metode atau teknik tertentu untuk memperoleh data yang diperlukan peneliti. Metode yang digunakan untuk pengumpulan data yang diperlukan dalam penelitian ini adalah: kuesioner tentang performance incentives, biaya pengumpulan informasi, hubungan antara manajer dengan karyawan, centrality bias, leniency bias yang dibagikan kepada responden.

\section{Pengukuran Variabel}

Variabel Performance Incentive merupakan variabel dependen. Performance Incentive merupakan persepsi responden terhadap kesesuaian insentif yang diterimanya berdasarkan pada kinerja yang dilakukannya pada organisasi (Bol,2011). Pada penelitian ini diukur dengan skala Likert yaitu STS (Sangat Tidak Setuju) skor 1 hingga SS (Sangat Setuju) skor 5. Semakin tinggi skor menunjukkan performance incentive semakin tinggi.

Variabel Biaya Pengumpulan Informasi merupakan variabel independen. Biaya pengumpulan informasi merupakan persepsi responden terhadap biaya yang dikeluarkan untuk mengumpulkan dan memelihara data yang menjelaskan kinerja sumber daya manusia, dimana data-data yang telah diperoleh tersebut merupakan data yang diperlukan perusahaan untuk meningkatkan keputusan sumber daya manusia (Bol,2011). Data-data tersebut berupa data produksi (volume penjualan dolar, unit yang diproduksi, jumlah kesalahan, jumlah produk cacat) serta data kerja (kecelakaan, turnover, absen, keterlambatan). Pada penelitian ini diukur dengan skala Likert yaitu STS (Sangat Tidak Setuju) skor 1 hingga SS (Sangat Setuju) skor 5. Semakin tinggi skor menunjukkan biaya pengumpulan informasi yang semakin efektif.

Hubungan antara manajer dengan karyawan merupakan persepsi responden terhadap kesinambungan interaksi yang terjalin antara manajer dengan karyawannya yang memudahkan proses pengenalan satu akan yang lain (Bol,2011). Pada penelitian ini diukur dengan skala Likert yaitu STS (Sangat Tidak Setuju) skor 1 hingga SS (Sangat Setuju) skor 5. Semakin tinggi skor menunjukkan hubungan antara manajer dengan karyawan yang semakin baik.

Centrality bias merupakan persepsi responden terhadap kecenderungan penilai memberikan penilaian pada prestasi karyawan dibawah rata-rata seharusnya (Bol,2011). Pada penelitian ini diukur dengan skala Likert yaitu STS (Sangat Tidak Setuju) skor 1 hingga SS (Sangat Setuju) skor 5. Semakin tinggi skor menunjukkan centrality bias yang semakin tinggi. 
Leniency Bias merupakan persepsi responden terhadap keadaan dimana penilai memberikan penilaian lebih tinggi daripada keadaan sebenarnya karena terlalu baik hati atau toleran (Bol,2011). Pada penelitian ini diukur dengan skala Likert yaitu STS (Sangat Tidak Setuju) skor 1 hingga SS (Sangat Setuju) skor 5. Semakin tinggi skor menunjukkan leniency bias yang semakin tinggi.

Teknik analis data yang digunakan pada penelitian ini mencangkup uji validitas dan reliabilitas kuesioner, uji asumsi klasik yang meliputi uji normalitas, uji heterositas, uji multikolinearitas. Kemudian juga dilakukan uji regresi berganda. Analisa validasi digunakan untuk menguji sejauh mana suatu alat pengukur dapat mengungkapkan ketetapan gejala yang dapat diukur (Hartono,2013). Uji validitas dalam penelitian dijelaskan sebagai suatu derajat ketetapan alat ukur penelitian tentang isi atau arti sebenarnya yang diukur (Hartono, 2013). Uji validitas digunakan untuk mengetahui apakah kuesioner dapat mengungkap data-data yang ada pada variabel-variabel penelitian secara tepat. Untuk mengukur validitas, digunakan teknik correlation product moment dengan cara mengkorelasikan skor butir dengan skor total.Uji reliabilitas adalah derajat ketetapan, ketelitian atau keakuratan yang ditunjukkan oleh instrument pengukuran (Hartono, 2013). Dalam penelitian ini teknik mencari reliabilitas menggunakan rumus alpha melalui perhitungan dengan menggunakan komputer dengan program SPSS. Cara perhitungan reliabilitas suatu data yaitu menggunakan Cronbach Alpha ( $\alpha)$.

Uji Normalitas bertujuan untuk menguji apakah dalam model regresi variabel penganggu atau residual memiliki distribusi normal. Uji Normalitas dilakukan dengan melakukan pengujian Kolmogorof-Smirnov. Jika nilai Asymp. Sig. > 0,05 maka data pada penelitian normal. Sebaliknya jika nilai Asymp. Sig. < 0,05 maka data tidak normal. (Ghozali, 2011).Uji Multikolinearitas bertujuan untuk menguji apakah model regresi ditemukan adanya korelasi antar variabel bebas. Model regresi yang baik seharusnya tidak terjadi korelasi di antara variabel bebas. Multikolinearitas dapat dilihat dari nilai tolerance dan lawannya Variance Inflation Factor (VIF). Untuk menunjukkan adanya Multikolinearitas adalah nilai Tolerance < 0,10 atau sama dengan nilai VIF > 10 (Ghozali, 2011).Uji Heteroskedastisitas bertujuan untuk menguji apakah dalam model regresi terjadi ketidaksamaan Variance dari Residual satu pengamatan ke pengamatan lain tetap maka disebut Homokedastisitas dan jika berbeda disebut Heterokedastisitas. Model regresi yang baik adalah tidak terjadi Heterokedastisitas. Uji ini dilakukan dengan Uji Glejser yaitu dengan meregresikan variabel independen dengan nilai absolute residual. Kriterianya adalah sebagai berikut (Ghozali, 2011) : Jika nilai signifikansi $>0,05$ maka tidak terjadi heteroskedastisitas. Sedangkan jika nilai signifikansi $<0,05$ maka terjadi heteroskedastisitas.

\section{HASIL DAN PEMBAHASAN}

Peneliti membagikan kuesioner kepada manajer perusahaan manufaktur di Semarang. Tabel 2 menyajikan rekapitulasi penyebaran kuesioner. Pada tabel 2, dapat dilihat bahwa dari 100 kuesioner yang disebar, ada sebanyak 23 kuesioner yang tidak kembali dan sebanyak 15 kuesioner yang tidak dapat diolah karena ada beberapa item pertanyaan mengenai variabel penelitian yang tidak diisi oleh responden. Jadi total kuesioner yang kembali dan dapat diolah sebanyak 62 kuesioner. 
Tabel 2.

Rekapitulasi Penyebaran Kuesioner

\begin{tabular}{|c|l|c|c|c|}
\hline No. & \multicolumn{1}{|c|}{ Nama Perusahaan } & $\begin{array}{c}\text { Kuesioner } \\
\text { yang } \\
\text { dikirim }\end{array}$ & $\begin{array}{c}\text { kuesioner } \\
\text { yang } \\
\text { kembali }\end{array}$ & $\begin{array}{c}\text { Kuesioner } \\
\text { yang dapat } \\
\text { diolah }\end{array}$ \\
\hline 1 & PT. Batam Textile Industri & 10 & 8 & 5 \\
\hline 2 & PT. Sri Boga Ratu Raya & 6 & 6 & 6 \\
\hline 3 & PT. Bonanza Megah Ltd & 6 & 6 & 6 \\
\hline 4 & PT.Agric Amarga Jaya & 8 & 7 & 5 \\
\hline 5 & PT. Gratia Husada Farma & 10 & 6 & 6 \\
\hline 6 & PT. Indosigma Surya Cipta & 6 & 6 & 6 \\
\hline 7 & PT. Dami Sariwana & 8 & 8 & 6 \\
\hline 8 & PT. Central Protein Prima & 8 & 8 & 5 \\
\hline 9 & PT. Antika Sanjaya & 4 & 4 & 4 \\
\hline 10 & PT. Singa Mas Indonesia & 5 & 4 & 3 \\
\hline 11 & CV. Plastik Laris Jaya & 3 & 3 & 3 \\
\hline 12 & CV. Trijaya Garmentama & 3 & 3 & 2 \\
\hline 13 & CV. Abadi Jaya & & 4 & 1 \\
\hline 14 & CV. Beta Endorphin & 4 & 4 & 0 \\
\hline 15 & Virgin Bakery & 3 & 0 & 0 \\
\hline 16 & Rapi Garment & 2 & 0 & 0 \\
\hline 17 & Jessy Cakes & 2 & 0 & 0 \\
\hline 18 & Bandeng Presto Juwana & 1 & 0 & 0 \\
\hline 19 & PT. Slamet Sumbing & 3 & 0 & 0 \\
\hline 20 & Monic Bakery & 2 & 0 & $\mathbf{6 2}$ \\
\hline 21 & Mahkota Berlian & 1 & 0 & \\
\hline 22 & De Koning Bakery & TOTAL & & 0 \\
\hline & & & 0 & 0 \\
\hline
\end{tabular}

Compare mean dilakukan untuk mengetahui tabulasi silang antara jenis kelamin,umur,lama bekerja,dan pendidikan terakhir responden terhadap semua variabel penelitian ini. Tabel 3 menampilkan hasil dari compare means pada penelitian ini. Ditinjau dari jenis kelaminnya, dapat dilihat bahwa responden pada penelitian ini yang berjenis kelamin laki-laki dan perempuan masing-masing sejumlah 31 orang.

Dari jenis kelaminnya, dapat diketahui bahwa manajer pria lebih memiliki kecenderungan dalam menilai karyawan dibawah rata-rata yang seharusnya, jika dibandingkan dengan manajer wanita.

Selain itu, manajer pria memiliki nilai persepsi yang lebih tinggi daripada manajer wanita terkait biaya yang dikeluarkan untuk pengumpulan informasi kinerja karyawan. Kemudian, dapat diketahui pula bahwa manajer wanita lebih memiliki kecenderungan untuk memberikan penilaian lebih tinggi dari keadaan sebenarnya, dibandingkan dengan manajer pria. Selain itu, manajer wanita memiliki nilai persepsi yang lebih tinggi dari manajer pria terkait dengan kesesuaian insentif yang diterimanya berdasarkan kinerjanya. Kemudian, manajer pria maupun manajer wanita memiliki persepsi yang hampir sama mengenai kesinambungan interaksi yang terjalin antara manajer dengan karyawannya. Dilihat dari nilai signifikannya, menunjukkan bahwa nilai signifikan $>0,05$ untuk semua variabel. Hal 
ini menunjukkan bahwa baik manajer wanita maupun pria tidak berbeda secara signifikan terkait persepsi mereka mengenai biaya pengumpulan informasi, centrality bias, leniency bias, hubungan antara manajer dan karyawan, dan performance incentive.

Tabel 3.

Compare Means

\begin{tabular}{|l|l|l|l|l|l|l|}
\hline Keterangan & Jumlah & BPI & CB & LB & Hub. & PI \\
\hline $\begin{array}{l}\text { Jenis } \\
\text { Kelamin : }\end{array}$ & & & & & & \\
\hline Wanita & 31 & 3,6129 & 2,9839 & 3,5081 & 4,0968 & 3,5258 \\
\hline Pria & 31 & 3,9355 & 3,4677 & 3,1613 & 4,0903 & 3,3290 \\
\hline Sig. & & $\mathbf{0 , 3 0 4}$ & $\mathbf{0 , 5 9 4}$ & $\mathbf{0 , 2 8 9}$ & $\mathbf{0 , 5 6 8}$ & $\mathbf{0 , 2 8 5}$ \\
\hline Umur : & & & & & & \\
\hline 21-30 tahun & 21 & 3,7202 & 3,2381 & 3,3214 & 3,9143 & 3,4810 \\
\hline 31-40 tahun & 30 & 3,7458 & 3,1333 & 3,3583 & 4,1467 & 3,4533 \\
\hline 41-50 tahun & 9 & 4,0556 & 3,8333 & 2,9167 & 4,4000 & 2,9222 \\
\hline$>50$ tahun & 2 & 3,5000 & 1,7500 & 5,0000 & 3,8000 & 4,7500 \\
\hline Sig. & & $\mathbf{0 , 5 1 2}$ & $\mathbf{0 , 3 0 8}$ & $\mathbf{0 , 3 3 5}$ & $\mathbf{0 , 0 5}$ & $\mathbf{0 , 1 0 9}$ \\
\hline $\begin{array}{l}\text { Lama } \\
\text { bekerja : }\end{array}$ & & & & & & \\
\hline 1-3 tahun & 15 & 4,0750 & 3,9500 & 2,4667 & 4,1200 & 2,8467 \\
\hline$>3$ tahun & 47 & 3,6782 & 2,9947 & 3,6117 & 4,0851 & 3,6128 \\
\hline Sig. & & $\mathbf{0 , 0 3 4}$ & $\mathbf{0 , 0 2 8}$ & $\mathbf{0 , 0 6}$ & $\mathbf{0 , 8 1 0}$ & $\mathbf{0 , 0 0 8}$ \\
\hline Pendidikan : & & & & & & \\
\hline SMA & 7 & 3,9643 & 4,2500 & 2,3571 & 4,3429 & 3,0000 \\
\hline D3 & 7 & 3,5714 & 1,8214 & 4,7143 & 4,0286 & 4,1714 \\
\hline S1 & 42 & 3,7500 & 3,1905 & 3,3393 & 4,0095 & 3,3457 \\
\hline S2 & 6 & 3,9583 & 3,9167 & 2,8333 & 4,4667 & 2,8500 \\
\hline Sig. & & $\mathbf{0 , 6 0 2}$ & $\mathbf{0 , 0 0 9}$ & $\mathbf{0 , 0 1 2}$ & $\mathbf{0 , 0 7 3}$ & $\mathbf{0 , 0 5 8}$ \\
\hline
\end{tabular}

Ditinjau dari usianya, dapat dilihat bahwa responden pada penelitian ini yang berumur 21-30 tahun sebanyak 21 orang, umur 31-40 tahun sebanyak 30 orang, umur 41-50 tahun sebanyak 9 orang, umur lebih dari 50 tahun sebanyak 2 orang. Dari segi usia, diketahui bahwa manajer yang berusia $>50$ tahun memiliki kecenderungan memberikan penilaian yang lebih tinggi dari keadaan yang sebenarnya. Namun,karena jumlah respondennya hanya 2 orang saja, maka peneliti lebih mencermati nilai mayoritas usia 31-40 tahun dan 21-30 tahun yang ternyata memiliki skor leniency bias (LB) yang hampir sama yaitu 3,3 sehingga dapat dikatakan bahwa mereka masih ragu-ragu dengan bias penilaian yang mereka lakukan. Begitu juga untuk persepsi manajer terkait biaya yang dikeluarkan untuk pengumpulan informasi kinerja karyawan, kecenderungan manajer memberikan penilaian di bawah ratarata, dan persepsi terkait kesesuaian insentif yang diterimanya berdasarkan kinerjanya menunjukkan bahwa antara manajer yang berusia 21-30 tahun dengan 31-40 tahun memiliki nilai yang relatif sama. Perbedaan nampak pada manajer yang berusia 21-30 tahun, dimana manajer diusia 21-30 tahun memiliki nilai yang lebih rendah daripada manajer usia 31-40 tahun terkait dengan kesinambungan interaksi yang terjalin antara manajer dengan karyawannya. Hal ini berarti manajer kelompok usia 21-30 tahun (tergolong muda),memiliki hubungan dengan karyawan tidak sebaik kelompok usia 31-40 tahun karena kemungkinan adanya faktor senioritas yang mana jika terdapat karyawan yang berusia lebih tua daripada manajer terkadang tidak suka diperintah oleh manajer yang berusia lebih muda. 
Dilihat dari nilai signifikannya, untuk variabel PI,BPI,CB,LB,dan hubungan manajer dengan karyawan memiliki nilai signifikan >0,05 sehingga hal ini berarti tidak ada perbedaan yang signifikan antara mereka yang berumur 21-30,31-40,41-50, dan yang lebih dari 50 tahun.

Ditinjau dari lama bekerjanya, dapat dilihat bahwa responden pada penelitian ini yang berkerja selama 1-3 tahun sebanyak 15 orang, dan yang bekerja lebih dari 3 tahun sebanyak 47 orang. Selain itu, dari lama bekerjanya dapat dilihat bahwa manajer yang bekerja antara 1-3 tahun memiliki nilai persepsi yang lebih tinggi daripada manajer yang bekerja lebih dari 3 tahun terkait biaya yang dikeluarkan untuk pengumpulan informasi kinerja karyawan. Hal ini dikarenakan manajer yang sudah bekerja lebih dari 3 tahun sudah memiliki pengalaman dalam mengumpulkan informasi terkait penilaian kinerja sehingga skoringnya lebih rendah. Selain itu, dapat diketahui bahwa manajer yang bekerja antara 1-3 tahun lebih memiliki kecenderungan untuk memberikan penilaian di bawah rata-rata yang seharusnya, hal ini dikarenakan kurangnya kemampuan manajer tersebut dalam membaca informasi-informasi yang terkumpul mengenai kinerja sehingga mereka akan lebih cenderung memberikan penilaian yang di bawah rata-rata. Kemudian dapat diketahui bahwa manajer yang bekerja 1-3 tahun memiliki kesinambungan interaksi yang terjalin antara manajer dengan karyawan lebih baik daripada mereka yang bekerja lebih dari 3 tahun, hal ini dikarenakan mereka masih merasa sebagai orang baru dan belum berpengalaman, sehingga mereka akan lebih menjalin interaksi dengan karyawannya dan lebih menampung aspirasi dari karyawannya untuk penyesuaian dirinya dalam lingkungan kerja. Dapat dilihat pula bahwa manajer yang bekerja di atas 3 tahun lebih memiliki kecenderungan untuk memberikan penilaian yang jauh lebih baik dari keadaan yang sebenarnya dibandingkan dengan mereka yang bekerja kurang dari 3 tahun. Sebab mereka memiliki hubungan yang baik dan lebih mengenal para karyawannya sehingga mereka akan cenderung memberikan penilaian yang jauh lebih tinggi dari yang seharusnya. Kemudian manajer yang bekerja di atas 3 tahun memiliki nilai persepsi yang lebih tinggi terkait dengan kesesuaian insentif yang diterimanya berdasarkan kinerja mereka. Dilihat dari nilai signifikannya, untuk variabel BPI,CB, dan PI signifikan. Sedangkan untuk LB dan Hubungan antara manajer dan karyawan tidak signifikan. Hal ini berarti ada perbedaan antara BPI, CB, dan PI tetapi mereka yang bekerja dibawah maupun diatas 3 tahun tidak berbeda secara signifikan ditinjau dari Leniency bias dan hubungan antara manajer dan karyawan.

Ditinjau dari pendidikannya, dapat dilihat bahwa responden pada penelitian ini kebanyakan memiliki pendidikan terakhir S1 yaitu 42 orang, kemudian SMA dan D3 masing-masing sebanyak 7 orang, dan yang berpendidikan terakhir S2 sebanyak 6 orang. Selain itu, ditinjau dari pendidikannya dapat diketahui bahwa mereka yang berpendidikan D3 lebih memiliki kecenderungan untuk memberikan penilaian yang jauh lebih tinggi dari keadaan yang sebenarnya. Sedangkan mereka yang berpendidikan SMA lebih memiliki kecenderungan memberikan penilaian di bawah rata-rata yang seharusnya, hal ini dikarenakan manajer yang hanya berpendidikan SMA tidak memiliki kemampuan dalam membaca informasi kinerja yang terkumpul sehingga mereka cenderung memberikan penilaian di bawah rata-rata. Selain itu, mereka yang berpendidikan SMA memiliki nilai persepsi yang lebih tinggi terkait biaya pengumpulan informasi kinerja karyawan dibandingkan dengan mereka yang berpendidikan S1, hal ini dikarenakan manajer yang berpendidikan S1 lebih memiliki pengetahuan dalam pengumpulan informasi terkait penilaian kinerja sehingga skoringnya lebih rendah. Kemudian mereka yang berpendidikan S2 memiliki kesinambungan interaksi yang lebih baik antara manajer dengan karyawan dibandingkan dengan mereka yang berpendidikan SMA,D3, dan S1. Dilihat dari nilai signifikannya, untuk variabel CB dan LB signifikan. Sedangkan untuk PI,BPI, dan Hubungan antara manajer dengan karyawan tidak signifikan. Hal ini berarti ada perbedaan 
antara CB dan LB, tetapi baik mereka yang berpendidikan SMA,D3,S1, maupun S2 tidak berbeda secara signifikan ditinjau dari PI,BPI,dan Hubungan manajer dan karyawan.

Tabel 4 menyajikan hasil uji hipotesis 1 dan hipotesis 3 menggunakan analisis regresi berganda. Berdasarkan tabel 4 diatas diketahui bahwa nilai signifikansi BPI (Biaya Pengumpulan Informasi) sebesar 0,010 dengan koefisien regresi 0,374. Walaupun berpengaruh signifikan namun arahnya tidak sesuai dengan prediksi. Jadi biaya pengumpulan informasi berpengaruh positif terhadap centrality bias. Hal ini menunjukkan bahwa meskipun perusahaan mempunyai informasi mengenai kinerja karyawan secara lengkap, namun hal tersebut tetap saja memunculkan bias, baik itu centrality bias maupun leniency bias dalam evaluasi kinerja. Penyebabnya adalah adanya sikap favoritism para penilai.

Tabel 4.

Uji hipotesis 1 dan 3

\begin{tabular}{|l|c|c|c|}
\hline \multicolumn{1}{|c|}{ Model } & Koefisien & T & Sig. \\
\hline BPI $\rightarrow$ CB manajer dan & 0,374 & 2,659 & 0,010 \\
\hline $\begin{array}{l}\text { Hubungan } \\
\text { karyawan } \rightarrow \text { CB }\end{array}$ & 0,627 & 2,120 & 0,038 \\
\hline
\end{tabular}

Seperti penelitian yang dilakukan oleh Tajfel (1982), mengungkapkan bahwa manajer memberikan penilaian lebih pada kelompok yang disukai. Meskipun manajer memiliki informasi yang lengkap mengenai kinerja karyawan, sikap favoritism penilai akan memunculkan leniency bias untuk in-group dan centrality bias untuk out-group. Selain itu, penelitian yang dilakukan oleh Brewer (1999) juga menunjukkan bahwa adanya perilaku favoritism pada penilai, cenderung memiliki keinginan untuk mempromosikan dan menjaga hubungan positifnya dengan yang in-group dan bersikap antagonis terhadap kelompok luar (out-group). Sehingga informasi mengenai kinerja karyawan yang dimiliki, tidak menjadi acuan dalam menilai kinerja karyawan. Dengan demikian, kelengkapan informasi kinerja karyawan tidak menjamin hilangnya bias dalam evaluasi kinerja.

Dari tabel 4 juga diketahui bahwa hubungan antara manajer dengan karyawan signifikan pada level 5\% dengan koefisien regresi 0,627. Dengan dimikian H3 diterima. Jadi hubungan antara manajer dengan karyawan berpengaruh positif terhadap centrality bias. Dimana semakin baik hubungan manajer dengan karyawan memunculkan bias dalam evaluasi kinerja. Hal ini dikarenakan atasan menjadi subjektif dalam menilai kinerja. Seperti yang dijelaskan dalam Theory Of Rating, bahwa hubungan atau interaksi antara manajer dengan karyawan dapat memunculkan bias, baik itu centrality bias maupun leniency bias. Sebab jika manajer melakukan penilaian secara akurat, maka manajer takut akan menimbulkan kritik,protes dari karyawan, serta konflik dengan karyawan yang dapat mengganggu hubungan manajer dengan karyawan sebagaimana mestinya.

Hasil penelitian ini didukung oleh penelitian yang dilakukan Breuer et al (2010) juga menyatakan bahwa bias evaluasi kinerja muncul ketika adanya jarak sosial yang dekat antara atasan dengan bawahan. Selain itu, hal ini juga didukung oleh penelitian yang dilakukan Golman dan Bhatia (2012), yang menunjukkan hasil bahwa hubungan yang dekat antara manajer dengan karyawan akan meningkat penilaian kinerja yang subjektif.

Hasil pengujian $\mathrm{H} 2$ dan $\mathrm{H} 4$ ditampilkan pada tabel 5. Dari tabel dapat diketahui bahwa nilai signifikansi BPI (Biaya Pengumpulan Informasi) terhadap LB sebesar 0,010 dengan koefisien regresi 0,366 . Karena arahnya tidak sesuai prediksi maka H2 ditolak. Jadi biaya pengumpulan informasi berpengaruh positif terhadap leniency bias. Hal ini menunjukkan bahwa meskipun perusahaan mempunyai informasi mengenai kinerja karyawan secara lengkap, namun hal tersebut tetap saja memunculkan bias, baik itu centrality bias maupun 
leniency bias dalam evaluasi kinerja. Menurut Theory Of Rating (1982), hal ini dipengaruhi oleh adanya hubungan dekat atau kekerabatan dengan yang dinilai dan penilai tidak mampu mencerna informasi yang ada karena informasinya terlalu banyak.

Tabel 5.

Uji hipotesis 2 dan 4.

\begin{tabular}{|l|c|c|c|}
\hline \multicolumn{1}{|c|}{ Model } & Koefisien & T & Sig. \\
\hline BPI $\rightarrow$ LB & 0,366 & 2,666 & 0,010 \\
\hline $\begin{array}{l}\text { Hubungan manajer dan karyawan } \rightarrow \\
\text { LB }\end{array}$ & 0,607 & 2,101 & 0,040 \\
\hline
\end{tabular}

Dimana Theory Of Rating yang dikemukakan oleh Wherry dan Bartlett (1982), mengungkapkan bahwa bias-bias yang terjadi dipengaruhi oleh beberapa faktor yaitu faktor penilai yang dikarenakan penilai kekurangan pengetahuan dalam mengolah informasi yang ada. Kemudian juga dipengaruhi oleh faktor orang yang dinilai seperti jenis kelamin,usia kerja. Dan yang terakhir, terjadi bias karena didorong oleh interaksi penilai dengan orang yang dinilai yang dapat dipengaruhi oleh ras dan gender. Dengan demikian, meskipun informasi kinerja karyawan yang dimiliki perusahaan itu lengkap, hal tersebut tidak menjamin hilangnya bias dalam evaluasi kinerja.

Dari tabel 5 juga dapat diketahui bahwa nilai signifikansi hubungan antara manajer dengan karyawan sebesar 0,040 dengan koefisien regresi 0,607. Dengan demikian H4 diterima. Hasil ini menunjukkan bahwa hubungan antara manajer dengan karyawan berpengaruh positif terhadap leniency bias. Dimana semakin baik hubungan manajer dengan karyawan memunculkan bias dalam evaluasi kinerja. Hal ini dikarenakan atasan menjadi subjektif dalam menilai kinerja. Seperti yang dijelaskan dalam Theory Of Rating, bahwa hubungan atau interaksi antara manajer dengan karyawan dapat memunculkan bias, baik itu centrality bias maupun leniency bias. Sebab jika manajer melakukan penilaian secara akurat, maka manajer takut akan menimbulkan kritik,protes dari karyawan, serta konflik dengan karyawan yang dapat mengganggu hubungan manajer dengan karyawan sebagaimana mestinya.

Hasil penelitian ini didukung oleh penelitian yang dilakukan Breuer et al (2010) juga menyatakan bahwa bias evaluasi kinerja muncul ketika adanya jarak sosial yang dekat antara atasan dengan bawahan. Selain itu, hal ini juga didukung oleh penelitian yang dilakukan Golman dan Bhatia (2012), yang menunjukkan hasil bahwa hubungan yang dekat antara manajer dengan karyawan akan meningkat penilaian kinerja yang subjektif.

Hasil pengujian H5 disajikan pada tabel 6. Dari tabel diketahui bahwa nilai signifikansi centrality bias sebesar 0,397 jauh diatas $5 \%$ sehingga $\mathrm{H} 5$ ditolak.

Tabel 6.

Uji hipotesis 5

\begin{tabular}{|c|c|c|}
\hline Model & T & Sig. \\
\hline $\begin{array}{c}\text { Centrality Bias } \rightarrow \text { PI karyawan di atas rata- } \\
\text { rata }\end{array}$ & $\begin{array}{c}- \\
0,859\end{array}$ & 0,397 \\
\hline
\end{tabular}

Jadi centrality bias tidak berpengaruh terhadap performance incentive karyawan yang di atas rata-rata. Ini berarti saat terjadi CB kepuasan karyawan akan hasil penilaian kinerja rendah. Walaupun di sebuah perusahaan terjadi kesalahan penilaian kinerja, karyawan yang "merasa" berprestasi ini tidak berani mengungkapkan kekecewaannya karena karyawan memiliki karakter "menerima". Oleh karena itu, meskipun terjadi centrality bias dimana penilai memberikan penilaian terhadap kinerja karyawan cenderung dibawah rata-rata, hal ini tidak 
mempengaruhi kinerja karyawan yang berada diatas rata-rata karena perilaku yang dimiliki oleh orang itu sendiri. Selain itu, Wright (1997) mengungkapkan bahwa seseorang memiliki kecenderungan perilaku atau perasaan sebagai "anggota" organisasi dan merasa puas bila dapat melakukan sesuatu yang lebih kepada organisasi. Sehingga meskipun karyawan dinilai dibawah rata-rata yang seharusnya, hal tersebut tidak mempengaruhi kinerja karyawan (Wright, 1997).

Selain itu, hal ini juga didukung oleh teori ketaatan (Obedience Theory). Teori ini menyatakan bahwa individu yang berkuasa mampu mempengaruhi perilaku bawahan (Hartanto dan Indra, 2001). Dalam teori ini, keataatan dapat bersifat compliance (takut terkena sanksi) dan bersifat identification (takut hubungan baiknya dengan seseorang ikut rusak). Jadi meskipun kinerja seorang karyawan dinilai di bawah rata-rata, kinerja mereka tidak terpengaruh, sebab mereka takut terkena sanksi jika tidak melakukan pekerjaan mereka sebagaimana mestinya dan juga mereka tetap bekerja secara baik untuk menjaga hubungan baiknya dengan atasan. Dengan demikian, terjadinya centrality bias dalam evaluasi kinerja karyawan tidak mempengaruhi kinerja karyawan tersebut.

Tabel 7.

\section{Uji hipotesis 6.}

\begin{tabular}{|c|c|c|}
\hline Model & T & Sig. \\
\hline $\begin{array}{c}\text { Centrality Bias } \rightarrow \text { PI karyawan di bawah rata- } \\
\text { rata }\end{array}$ & - & 0,231 \\
\hline
\end{tabular}

Hasil pengujian H6 disajikan pada tebel 7. Dari tabel diketahui bahwa nilai signifikansi untuk centrality bias sebesar $0.231>0.05$ artinya H6 ditolak. Jadi centrality bias tidak berpengaruh terhadap performance incentive karyawan yang di bawah rata-rata. Hal ini berarti karyawan dengan kinerja di bawah rata-rata merasa enggan untuk meningkatkan kinerja karena mereka merasa dengan kinerja yang buruk saja, mereka dapat memperoleh insentif yang sama dengan karyawan yang berkinerja baik. Jadi meskipun terjadi centrality bias dalam evaluasi kinerja karyawan, ternyata hal ini tidak berpengaruh terhadap kinerja orang tersebut. Hal ini dipengaruhi oleh faktor-faktor lain yang mempengaruhi kinerja seseorang, seperti etos kerja dan juga profesionalisme setiap pribadi. Etos merupakan karakter, cara hidup, kebiasaan, dan cara bertindak seseorang (Khasanah, 2004:8). Etos kerja dapat mempengaruhi kinerja. Etos kerja terwujud melalui perilaku kerja sehingga meskipun penilai memberikan penilaian kinerja yang cenderung di bawah rata-rata, hal itu tidak mempengaruhi kinerja karyawan. Sebab setiap orang memiliki pandangan kerja sendiri yang diwujudkan melalui perilaku kerja mereka (Sinamo, 2003:2).

Centrality bias tidak memberikan pengaruh terhadap kinerja karyawan juga disebabkan oleh profesionalisme orang tersebut. Seperti yang diungkapkan oleh Caroli (1993 : 4), bahwa profesionalisme mengacu pada sikap. Profesionalisme ini dibentuk dari ketrampilan, tingkat pendidikan seseorang, dan pengalaman kerja seseorang. Sehingga pegawai yang memiliki sikap profesionalisme akan melakukan pekerjaan dengan sungguh-sungguh dan menganggapnya penting bagi karier mereka. Jadi, ketika terjadi bias dalam evaluasi kinerja karyawan, hal itu tidak akan mempengaruhi kinerja karyawan.

Tabel 8.

Uji hipotesis 7

\begin{tabular}{|c|c|c|}
\hline Model & T & Sig. \\
\hline Leniency Bias $\rightarrow$ PI & 18,853 & 0,000 \\
\hline
\end{tabular}


Hasil pengujian $\mathrm{H} 7$ disajikan pada tabel 8. Berdasarkan tabel diketahui bahwa nilai signifikansi untuk leniency bias sebesar $0.000<0.05$ artinya $\mathrm{H} 7$ diterima. Jadi Leniency bias berpengaruh terhadap performance incentive karyawan. Menurut discrepancy theory, kepuasaan atau ketidakpuasaan karyawan terhadap pekerjaannya itu tergantung dari kesenjangan antara apa yang diinginkan dengan apa yang diperoleh karyawan tersebut. Jika yang didapatkan karyawan ternyata lebih besar dari apa yang diinginkannya maka karyawan akan merasa puas. Semakin karyawan merasa puas, maka karyawan akan semakin meningkatkan kinerjanya. Sehingga jika dalam evaluasi kinerja terjadi leniency bias, maka hal ini akan berpengaruh positif terhadap kinerja maupun insentif karyawan. Dimana leniency bias ini merupakan situasi ketika manajer/penilai memberikan penilaian yang terlalu baik/terlalu tinggi dibandingkan dengan keadaan sebenarnya. Dengan demikian, insentif yang diterima karyawan akan jauh lebih tinggi dari apa yang seharusnya diterima oleh karyawan tersebut. Oleh karena itu, karyawan akan merasa termotivasi untuk meningkatkan kinerjanya.

Namun, leniency bias ini dapat berdampak negatif terhadap kinerja dan insentif karyawan. Dalam penelitian yang dilakukan oleh Golman dan Bhatia (2012), menunjukkan bahwa leniency bias ini berdampak negatif terhadap usaha dan produktivitas karyawan dalam jangka panjang dan juga leniency bias ini mendistorsi upah. Selain itu, hal ini juga didukung oleh penelitian yang dilakukan Gurbuz dan Dikmenli (2007), yang menyatakan bahwa sangat sulit bagi ratees melihat semua orang mendapatkan penilaian yang sama dan ratees menganggap sistem penilaian tersebut tidak adil, meskipun penilaian yang dilakukan tersebut mengacu pada leniency bias. Sehingga kesalahan peniliaian tersebut dapat melemahkan motivasi kerja dan kinerja karyawan.

\section{SIMPULAN}

\section{Kesimpulan}

Berdasarkan pada hasil pengujian, maka dapat diperoleh kesimpulan bahwa biaya pengumpulan informasi berpengaruh positif terhadap centrality bias maupun leniency bias. Hal ini menunjukkan bahwa meskipun informasi yang dimiliki perusahaan tersebut lengkap, hal itu tetap saja memunculkan bias dalam evaluasi kinerjanya. Hal ini dipengaruhi oleh sikap favoritism para penilai, sehingga data yang terkumpul tidak menjadi acuan dalam penilaian kinerja. Kemudian hubungan manajer dengan karyawan berpengaruh positif terhadap centrality bias maupun leniency bias. Dimana semakin baiknya hubungan manajer dengan karyawan, maka penilaian kinerja yang dilakukan akan semakin subjektif dan menimbulkan bias dalam evaluasi kinerja. Selain itu, centrality bias tidak berpengaruh terhadap performance incentive karyawan yang diatas rata-rata maupun dibawah rata-rata. Sedangkan leniency bias berpengaruh terhadap performance incentive karyawan.

\section{Saran}

Dilihat dari hasil penelitian ini dapat diketahui bahwa biaya yang dikeluarkan perusahaan untuk mengumpulkan data kinerja karyawan sudah efektif sehingga perusahaan memiliki informasi yang lengkap tentang kinerja karyawan. Namun, kelengkapan informasi tersebut tetap saja tidak menjamin hilangnya bias dalam penilaian kinerja. Sebab para manajer perusahaan tetap melakukan penilaian secara subjektif tanpa memperhatikan informasi-informasi yang terkumpul tersebut. Padahal budaya di Indonesia itu menerapkan sistem kompensasi yang berbasis kinerja. Tentu saja hal ini akan merugikan karyawan di perusahaan. 
Saran yang bisa diberikan untuk perusahaan yaitu : Pertama, perusahaan harus menetapkan standar penilaian kinerja yang jelas. Jelas dalam arti, standar ini tidak hanya diketahui oleh penilai namun juga yang dinilai (karyawan). Jika karyawan mengetahui standar penilaian dengan jelas, maka karyawan akan mengetahui dengan bekerja seperti yang ia lakukan,ia akan dinilai sesuai standar yang ada. Jadi dasar yang dipakai penilai tidak asal. Karyawan pun bisa protes (menurut dasar acuan atau standar yang dipakai) ketika penilaian yang dilakukan oleh penilai tidak sesuai standar. Jadi secara sederhana dikatakan ada keterbukaan dan kejelasan mengenai sistem penilaian kinerja. Kedua, hubungan antara manajer dan karyawan harus jelas tugas dan tanggung jawabnya. Misalnya ada deskripsi pekerjaan dan tanggung jawab. Selain itu, diketahui bahwa adanya komunikasi yang aktif antara manajer dengan karyawannya merupakan hal yang paling mempengaruhi kedekatan hubungan manajer dengan karyawannya sehingga mendorong terjadinya leniency bias maupun centrality bias. Maka dari itu, sebaiknya manajer melakukan komunikasi dengan karyawan seperlunya saja dan komunikasi yang dilakukan sebaiknya hanya yang berkaitan dengan pekerjaan saja. Maka dengan adanya kejelasan tugas dan tanggung jawab, serta komunikasi yang seperlunya ini diharapkan dapat mengurangi bias yang terjadi.

\section{DAFTAR PUSTAKA}

Baker, G. P., R. Gibbons, and K. J. Murphy. 1994. Subjective Performance Measures in Optimal Incentive Contracts. The Quarterly Journal of Economics 109 (4): 1125-1156.

Berger, J., C. Harbring, and D. Sliwka. 2010. Performance Appraisals and the Impact of Forced Distribution: An Experimental Investigation. Working Paper, IZA 5020: 1-44.

Bol, J. C. 2008. Subjectivity in Compensation Contracting. Journal of Accounting Literature 27: 1-27.

Bol, J. C. 2011. The Determinants and Performance Effects of Managers' Performance Evaluation Biases. The Accounting Review, 86 (5), 1549-1575.

Bol, J. C. and S. D. Smith. 2011. Spillover Effects in Subjective Performance Evaluation: Bias and the Asymetric Influence of Controllability. The Accounting Review, 86 (4), 1213 1230 .

Bol, J.C. 2007. The Determinants and Performance Effects of Supervisor Bias. The Accounting Review 89 (3): 1407-1439.

Breuer, K., P. Nieken, and D. Sliwka. 2010. Social Ties and Subjective Performance Evaluations: An Empirical Investigation. Review Management Science, 7, 141-157.

Brewer, M. B. 1999. The Psychology Of Prejudice : Ingroup Love or Outgroup Hate. Journal of social issues, Vol.55,No.3.

Carolin, B.1993. Menjadi Sekretaris Profesional. Edisi Pertama. Jakarta : Bina Rupa Aksara. 
Ghozali, I. 2011. Aplikasi Analisis Multivariate Dengan Program IBM SPSS19.Edisi Kelima.Semarang : Universitas Diponegoro.

Gibbs, M., K. A. Merchant, W. A. Van der Stede, and M. E. Vargus. 2004. Determinants and effects of subjectivity in incentives. The Accounting Review 79 (2): 409-436.

Golman, R. and S. Bhatia. 2012. Performance Evaluation Inflation and Compression. Accounting, Organizations and Society, 37, 534-543.

Gurbuz, S. and O. Dikmenli. 2007. Performance Appraisal Biases In A Public Organization: An Emprical Study. Kocaeli Üniversitesi Sosyal Bilimler Enstitüsü Dergisi (13) 2007 / 1 $\therefore$ 108-138.

Handojono, M. dan M. Sholihin.2014. Bagaimana Mengurangi Bias Kemurahan Hati Dalam Penilaian Kinerja Subjektif? Sebuah Pendekatan Eksperimen. Jurnal Akuntansi dan Keuangan Indonesia 11 (1): 40 - 56.

Harris, M. M. 1994. Rater motivation in the performance appraisal context: A theoretical framework.Journal of Management 20 (4): 737-756.

Hartanto, H. dan I. Wijaya.2001.Analisis Pengaruh Tekanan Ketaatan Terhadap Judment Auditor. Jurnal akuntansi dan manajemen 2 (3).

Hartono, J. 2013. Metodologi Penelitian Bisnis.Edisi Keenam. Yogyakarta: BPFE.

Sinamo, J. 2003. Etos Kerja Profesional.Jakarta : PT.Spirit Mahardika.

Jensen, M. C and W.H. Meckling.1976.The Theory of The Firm: Manajerial Behaviour, Agency Cost, and Ownership Structure.Journal of Financial and Economics 3:305-360.

Khasanah, U. 2004. Etos Kerjasama Menuju Puncak Prestasi.Yogyakarta : Harapan Utama.

Kusdi. 2009. Teori Organisasi dan Administrasi.Jakarta : Salemba Humanika.

Masdupi, E. 2005. Analisis Dampak Struktur Kepemilikan Pada Kebijakan Hutang Dalam Mengontrol Konflik Keagenan. Jurnal Ekonomi dan Bisnis Indonesia 20 (1): 57-59.

Moers, F. 2005. Discretion and bias in performance evaluation: The impact of diversity and subjectivity. Accounting, Organizations and Society 30 (1): 67-80.

Prendergast, C. dan R. H. Topel.1996. Favoritism in Organizations.Journal of Political Economy, 104(5): 958-78.

Prendergast, C. 1999. The provision of incentives in firms. Journal of Economic Literature 37 (1): 7-63.

Tajfel, H. 1982. Sosial Psychology Of Intergroup Relations. Annual Reviews Psychol 1982, 33:1-39. 
Jurnal Akuntansi Bisnis, Vol. 17, No. 2, September 2019

ISSN 1412-775X (media cetak) | 2541-5204 (media online)

Wherry, R. J. and C. J. Bartlett. 1982. The Control of Bias Ratings: A Theory of Rating. Personnel Psychology, 35, 521-552.

Wright, S. 1997. The Extended Contact Effect :Knowledge of Cross-Group Friendships and Prejudice. Journal of Personality and Social Psychology,1997, Vol.73,No.1:73-90. 